Avalaible online: https://ejournal.iai-tribakti.ac.id/index.php/pgmi

Article doi: https://doi.org/10.33367/iiee.v1i2.1223

\title{
Analisis Tingkat keterbacaan Buku Tematik Siswa Kelas Rendah Madrasah Ibtidaiyah Tahun Ajaran 2017-2018
}

\author{
${ }^{1}$ Aly Mashar, ${ }^{2}$ Bintang Aji Permana Caromalela \\ ${ }^{1}$ IAIN Surakarta, ${ }^{2}$ IAIN Surakarta \\ 1alymashariainskt@gmail.com, ${ }^{2}$ bintangajipermanacaromalela@gmail.com
}

\begin{abstract}
This paper examines the level of readability of integrated thematic books of low grade Madrasah Ibtidaiyah level using two analysis tools, namely fry and raygor charts. Both of these instruments are used to provide a picture of reading thematic books for low class, which later can be used as a platform for future improvement of textbooks. The form of this research is the library research (Library Research) analysis tool using two analytical tools, namely fry and raygor charts. The results of this study are: 1), grade 1 thematic books according to the fry chart analysis of 8 existing theme books, none of the books match the grade 1 level, whereas according to the raygor chart there is only one book that is suitable, namely theme book 1 ; 2) grade 2 books according to the results of fry chart analysis there are 2 suitable themes, namely theme books 4 and 6, whereas according to the raygor chart there are only 1 appropriate theme books, namely theme book 6; and 3) grade 3 books according to fry charts, there is only 1 suitable theme book, namely theme book 3 , while according to raygor chart there are 6 appropriate theme books, namely theme books 3, 4, 5, 6, 7, and 8.
\end{abstract}

Key Word: Readability, Student Thematic Book, Low Class Madrasah Ibtidaiyah

\section{Pendahuluan}

Buku teks pelajaran hingga kini masih dianggap sebagai bahan ajar yang paling utama. Ini terlihat hampir dalam berbagai institusi pendidikan, dari jenjang yang paling dasar hingga pendidikan yang paling tinggi, pada umumnya menggunakan buku teks pelajaran sebagai bahan ajar utamanya. Hal ini membuktikan pula bah-wa keberadaan buku teks pelajaran merupakan bagian yang tidak terpisahkan dari proses pembelajaran yang berlansung dalam berbagai institusi pendidikan de- wasa ini. Buku teks pelajaran juga merupakan bagian penting dari kegiatan pembelajaran. ${ }^{1}$

Buku teks pelajaran seharusnya mampu menyajikan bahan ajar dalam bahasa Indonesia yang baik dan benar. Hal ini sesuai dengan Peraturan Pemerintah Nomor 19 Tahun 2005 ten-tang Standar Nasional Pendidikan bahwa buku teks pelajaran termasuk ke dalam sarana pendidikan yang perlu diatur standar mutunya, sebagaimana halnya standar mutu pendidikan lainnya, yaitu standar isi, standar proses, standar kom-petensi lulusan, standar pendidikan
1 Holofatuz,N.2015."Analisis Tingkat Keterbacaan dalam Buku Teks Pembelajaran el Bidayah: Journal of Islamic Elementary Education Volume 1, Nomor 2, September 2020
Tematik Terpadu Kurikulum 2013 Tingkat SD/MI Kelas 2". NOSI, 3(2). 
Oleh: Aly Mashar, Bintang Aji Permana Caromalela

dan kependidikan, standar sarana dan prasarana, standar pengelolaan, standar pembiayaan dan standar penialaian pendidikan. Sementara "Buku teks berkaitan erat dengan kurikulum yang berlaku. Buku teks yang baik haruslah re-levan dan menunjang pelaksanaan kurikulum. Lebih dari itu, buku teks harus mampu menunjang akti-vitas dan kreativitas siswa. Semakin baik buku teks, maka semakin baik pula pengajaran mata pelajaran yang ditunjang-nya". ${ }^{2}$

Atas dasar hal di atas, maka buku teks pelajaran yang digunakan di sekolah-sekolah harus memiliki kebenaran isi, penyajian yang sistematis, penggunaan kebahasaan dan keterbacaan yang baik, grafika yang fungsional, dan kesesuaian dengan kurikulum yang sedang berjalan. Buku pelajaran sengaja dirancang khusus untuk menjadi teman bagi belajar siswa. Dengan itu, siswa diarahkan untuk mampu belajar secara mandiri atau berkelompok, baik pada situasi pembelajaran di dalam kelas maupun diluar kelas. Oleh karena hal tersebut, penyajian di dalamnya memungkinkan siswa untuk belajar secara mandiri tanpa bergantung terhadap guru. ${ }^{3}$

Buku teks pelajaran menurut kurikulum 2013 adalaha berbasis tematik. Artinya di dalamnya terdapat beberapa unit atau bab yang masing-masing ber-isikan tema tertentu. Setiap unit atau bab tersebut diikat oleh sebuah tema tertentu yang terdiri atas beberapa kompetensi dasar. Kompetensi dasar ini diturunkan berasal dari Standar Isi yang telah disusun oleh Ba-dan Standar Nasional Pendidikan (BSNP). Penempatan setiap Kompetensi Dasar pada masing-

2 Taufina. 2017. Buku tematik kurikulum 2013 Kelas II tema Pengalamanku. Jakarta: Kementerian Pendidikan dan Kebudayaan.

3 Holofatuz,N.2015."Analisis Tingkat Keterbacaan dalam Buku Teks Pembelajaran Tematik Terpadu Kurikulum 2013 Tingkat SD/MI Kelas 2". NOSI, 3(2)

50 masing unit atau bab diurutkan berdasarkan tingkat kesukaran masingmasing kompetensi, yaitu mulai dari kompetensi yang mudah ditempatkan pada unit atau bab awal dan kompetensi yang sulit ditempatkan pada unit atau bab selanjutnya. ${ }^{4}$

Dengan demikian penguasaan konsep oleh siswa berjalan secara runtut dan bertahap, mulai dari konsep yang paling mudah hingga konsep yang paling sulit. Kompetensi dasar pada sebuah unit pembelajaran menjadi sebuah sub-bab, sehingga setiap unit dalam buku ini terdiri atas beberapa sub-bab. Agar kompetensi dasar yang sudah ditetapkan dalam Standar Isi dapat benar-benar dikuasai oleh siswa, penyajiannya dirancang sedemikian rupa sehingga siswa dapat dengan mudah menguasai konsep setiap kompetensi dasar, dan selanjutnya meng-aplikasikan konsep yang sudah dipelajari kepada peri-laku atau tindakan.

Aspek keterbacaan dalam buku teks pelajaran berkaitan dengan tingkat kemudahan bahasa (yakni pilihan kata dan efektifitas penggunaan kalimat) serta tingkat kemudahan membaca (berkaitan dengan penyajian teks atau tulisan dan kegrafikan). Hal ini perlu dipertimbangkan secara serius untuk dituangkan dalam buku teks pelajaran yang akan digunakan siswa dalam proses kegiatan belajar mengajarnya sehingga perlu disesuaikan dengan karakteristik siswa sesuai dengan jenjang pendidikannya. ${ }^{5}$

Berdasarkan wawancara peneliti dengan beberapa guru Madrasah Ibtidaiyah

4 Holofatuz,N.2015. "Analisis Tingkat Keterbacaan dalam Buku Teks Pembelajaran Tematik Terpadu Kurikulum 2013 Tingkat SD/MI Kelas 2". NOSI, 3(2)

5 Holofatuz,N.2015."Analisis Tingkat Keterbacaan dalam Buku Teks Pembelajaran Tematik Terpadu Kurikulum 2013 Tingkat SD/MI Kelas 2". NOSI, 3(2), h.123

el Bidayah: Journal of Islamic Elementary Education Volume 1, Nomor 2, September 2020 
Kelas III di wilayah Surakarta, yang dilaksanakan pada tanggal 23 Juli 2018, terdapat masalah keterbacaan dalam pengelolaan pengajaran membaca oleh sebagian guru kelas rendah belum mendapatkan perhatian. Sebagaian besar guru kelas rendah tidak mengetahui bagaimana cara mengukur tingkat keter-bacaan teks, sehingga mereka tidak melakukan analisis buku teks sebelum mereka mengguna-kannya sebagai bahan ajar. Hal ini jelas akan berimbas pada keberhasilan proses belajar mengajar karena, jika buku teks tersebut dinilai jelek keterbacaannya, proses pemahaman siswa pada buku teks tersebut terganggu.

Terkait tingkat keterbacaan buku teks, sudah ada beberapa penelitian yang melakukannya, diantaranya: penelitian Mahardika Dewi Pratiwi (Skripsi PGSD IKIP PGRI Semarang, 2013) dengan judul "Analisis Buku Pelajaran Bahasa Indonesia Kelas 1 SD DABIN II Kecamatan Candisari Sema-rang dan penelitian Euis Ananiah dan Nesa Nurhasanah dalam Jurnal Pendidikan Guru Sekolah Dasar STKIP Subang tahun 2016 dengan judul "Tingkat Keterbacaan Wacana Pada Buku Paket Kurikulum 2013 Kelas 4 Sekolah Dasar Meng-gunakan Grafik Fry”.

Berdasarkan latar belakang $\mathrm{di}$ atas, peneliti tergerak untuk menganalisis tingkat keterbacaan buku teks pembe-lajaran tematik terpadu tingkat Madrasah Ibtidaiyah (MI) pada jenjang kelas rendah dengan menggunakan grafik fry dan grafik raygor.

\section{Metode}

Metodologi penelitian, bentuk dari penelitian ini adalah library research ${ }^{6}$ dengan mengabil objek 24 buku tema kelas 1 , 2, dan 3 Madrasah Ibtidaiyyah yang diterbitkan oleh Kementerian Pend-idikan dan Kebudayaan Republik Indo-nesia (Ke- mendikbud RI). Kemudian, terkait analisisnya peneliti menggunakan dua alat, yaitu grafik fry dan raygor.

\section{Temuan dan Pembahasan Temuan Penelitian}

\section{A. Tingkat Keterbacaan, Grafik Fry dan Raygor}

\section{Tingkat Keterbacaan Buku Teks}

Keterbacaan adalah adalah keseluruhan unsur bacaan yang mempengaruhi keberhasilan yang dicapai se-kelompok pembaca dengan bahan tersebut. Sejatinya, keterbacaan adalah perihal yang dapat dibacanya teks secara cepat, mudah dimen-gerti, dipahami, diingat. Keterbacaan sering dikaitkan dengan ihwal terbaca tidaknya materi bacaan oleh pembacanya. ${ }^{7}$

Keterbacaan dalam istilah bahasa Inggris disebut readability. Keterbacaan da-lam pengajaran membaca memperhati-kan tingkat kesulitan materi bacaan yang pantas dibaca oleh peserta didik. Keterbacaan merupakan ukuran tentang sesuai atau tidaknya suatu bacaan bagi pembaca tertentu dilihat dari segi tingkatan kesukarannya atau kemudahan waca-nanya. Dalam keterbacaan teks ada dua faktor umum yang mempengaruhi keterbacaan sebuah teks, yaitu unsur linguistik yang digunakan untuk menyampaikan pesan dan Unsur keterampilan membaca para pembaca. Oleh karena itu keterbacaan mempersoalkan tingkat tingkat kesulitan atau tigkat kemudahan suatu bahan bacaan tertentu bagi peringkat pembaca tertentu. Keterbacaan merupakan ukuran tidak atau sesuainya suatu bacaan bagi pembaca tertentu dilihat

6 Moeleong,J Lexy.2016. Metodologi Penelitian Kualitatif Edisi Revisi.Bandung:PT Remaja Rosdakarya.
7 Setio Isnoyo, dkk. 2017. Buku tematik kurikulum 2013 Kelas I tema Keluargaku. (Jakarta: Kementerian Pendidikan dan Kebudayaan, 2014). H. 27 
Oleh: Aly Mashar, Bintang Aji Permana Caromalela

dari segi tingkat kesulitan atau kemudahan wacananya. ${ }^{8}$

Tingkat keterbacaan biasanya dinyatakan dalam bentuk peringkat kelas. Setelah melakukan pengukuran keterbacaan sebuah wacana, orang dapat mengetahui kecocokan materi bacaan tersebut dengan peringkat kelas tertentu. Menurut penjelasan tersebut dapat dijelaksan bahwa keterbacaan tergantung kosa kata dan kontribusi kalimat yang digunakan oleh penulis dalam tulisannya. Sementara faktor-faktor lainnya yang dapat mempengaruhi tingkat keterbacaan teks terjemahan, penggunaan kata asing dan daerah, penggunaan kalimat dan kata taksa, penggunaan kalimat tidak lengkap, dan alur piker yang tidak runtut. Keterbacaan ber-kaitan dengan dengan keseluruhan unsur yang terdapat pada teks atau materi bacaan, untuk menentukan tingkat keterbacaan teks atau materi bacaan dapat di ukur dengan berbagai formula atau rumus.

Indikator keterbacaan suatu teks bukan dialog atau buku adalah keterbacaan masing-masing paragraphnya. Untuk dapat memahami suatu teks perlu pemahaman yang utuh dari masingmasing paragraf pembentuk teks. Rumit atau tidaknya suatu gagasan yang akan dikomunikasikan oleh suatu teks dapat dilihat dari cacah paragrafnya. Teks yang terdiri dari banyak paragraf memi- liki gagasan utama yang tidak sederhana sehingga memerlukan tahapan-tahapan berfikir yang masing-masing tertuang dalam bentuk paragraf. Dengan demikian, cacah paragraf suatu teks menunjukkan cacah pokok pikiran dan atau subpokok pikiran yang diguna-kan oleh penulis untuk mengkomunikasikannya kepada pembaca. ${ }^{9}$

Unsur pokok suatu paragraf adalah kalimat. Untuk dapat menangkap pokok pikiran suatu paragraf diperlukan pemahaman terhadap kalimat-kalimat pembentuknya. Suatu paragraf memiliki keterbacaan yang tinggi apabila sebagian besar kalimat yang digunakan berupa kalimat sederhana dan pendek serta dijalin dengan memenuhi kriteria kesatuan dan kepaduan. Tuntutan penggunaan kalimat-kalimat pendek dan sederhana itu akan berpengaruh terhadap panjang paragraf. Sebuah paragraf yang memanfaatkan kalimat-kalimat pendek dan sederhana akan cenderung berupa paragraf yang panjang. Dengan kata lain, paragraf yang bersangkutan akan memiliki cacah kalimat yang begitu banyak. ${ }^{10}$

Maka berdasarkan penjelasan diatas bahwa selain kalimat, pemilihan kata juga dapat berpengaruh terhadap sukar atau mudahnya tingkat keterbacaan dalam pe-mahaman kalimat. Kata-kata yang berfre-kuensi pemakaian tinggi

10 Didin Budiman.2017.Karakteristik Siswa Sekolah Dasar.Bahan Ajar Mata Kuliah Penjas Universitas Muhammadiyah Sidoarjo. 57 kurikulum 2013 Kelas III tema Permainan Tradisional. (Jakarta:Kementerian Pendidikan dan Kebudayaa), h.123

9 Didin Budiman.2017.Karakteristik Siswa Sekolah Dasar. Bahan Ajar Mata Kuliah Penjas Universitas Muhammadiyah Sidoarjo. 53 52 el Bidayah: Journal of Islamic Elementary Education Volume 1, Nomor 2, September 2020 
lebih mudah dipahami dibanding dengan kata-kata ya-ng jarang dipakai.

Selanjutnya terkait unsur dan urgensi tingkat keterbacaan, menurut Dale dan Chall sebagaimana dikutip Sarwo, ada tiga, yaitu: pertama, unsur pemahaman yang meliputi Penghubungan antara po-kok-pokok pikiran dalam bacaan dengan pengalaman pembaca; kedua, kefasihan, yaitu kemampuan pembaca untuk membaca teks tertentu dengan kecepatan optimal: dan ketiga, faktor-faktor motivasi yang akan mempengaruhi minat. Dalam hal ini dapat disimpulkan bahwa keterbacaan dapat diartikan sebagai keseluruhan unsur di dalam materi cetak tertentu yang mempengaruhi keberhasilan pem-baca yang meliputi pemahaman dan kecepatan yang optimal. Lanjut Sarwo, tingkat keterbacaan adalah jika suatu teks terlalu sulit, kecepatan membaca seseorang akan berkurang dan harus membaca ulang untuk mendapatkan informasinya. Jika suatu teks tersebut terlalu mudah, seseorang pembaca akan cepat bosan. ${ }^{11}$ Untuk itu diperlukan penyesuaian antara tingkat kesulitan teks dengan pembacanya. Hal tersebut menjadi alasan penting atau urgensinya pengukuran tingkat keterbacaan itu sebelum sebuah teks di-gunakan sebagai sumber belajar.

Hal lain yang harus dipertahikan dalam tingkat keterbacaan buku teks siswa adalah kategorisasitingkat keterbacaan siswa sekolah dasar. Menurut Nurlaili dalam proses membaca terdapat dua komponen

11 Mahardika, Dwi Pratiwi.2013. Analisis Buku Pelajaran Bahasa Indonesia Kelas I SekolahDasarKecamatan Candisari Semarang. Skripsi. Semarang: Fakultas Ilmu Pendidikan IKIP PGRI Semarang utama yang bekerja secara dominan, yakni kerja mata untuk melihat lambang-lambang grafis, dan kerja otak untuk memahami dan memaknai lambang-lambang grafis tadi menjadi sebuah informasi yang utuh dan lengkap. Maka terdapat kategorisasi yang berhubungan dengan panjang kalimat, jumlah suku kata,dan dan tingkat kesulitan tingkat keterbacaan, seperti terlihat pada tabel berikut:

\begin{tabular}{|c|c|}
\hline Kelas & Jumlah Kata \\
\hline 1 & $25-75$ \\
\hline 2 & $75-125$ \\
\hline 3 & $125-175$ \\
\hline 4 & $175-225$ \\
\hline 5 & $225-275$ \\
\hline 6 & $275-325$ \\
\hline
\end{tabular}

\section{Grafik Fray dan Raygor}

Grafik Fry adalah formula keterbacaan yang dikembangkan oleh Edward Fry yang kemudian di kenal dengan grafik Fry. Harjasujana mengungkapkan bahwa grafik fry mulai dipublikasikan pada tahun 1997, dalam majalah Journal Of Reading dan grafik aslinya dibuat pada tahun 1968. Harjasujana dan Yeti Mulyati mengemukakan bahwa, dari sekian banyak formula keterbacaan yang diperkenalkan, grafik fry dan grafik raygor merupakan dua alat yang dipandang praktis dan mudah menggunakannya. Namun karena alat tersebut diciptakan untuk mengukur wacana bahasa Inggris, maka pemakaian-nya untuk wacana Bahasa Indonesia harus disesuaikan. Di bawah ini adalah gambar Grafik Fry. ${ }^{12}$

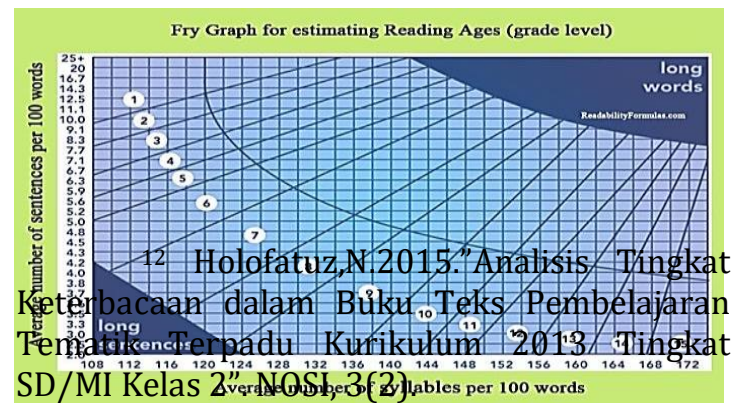


Oleh: Aly Mashar, Bintang Aji Permana Caromalela

136,8 dibulatkan menjadi 137 suku kata.

Berdasarkan gambar di atas, maka terlihat grafik Fry ini melibatkan dua faktor, yaitu panjang-pendeknya kali-mat dan tingkat kesulitan kata yang ditandai oleh jumlah suku yang mem-bentuk setiap kata dalam Wacana.

Menurut Harjasujana dan Yeti Mulyati, petunjuk penggunaan grafik Fry yang sudah disesuaikan dengan karakteristik bahasa Indonesia yaitu:

a. Pilih penggalan yang representatif dari wacana yang hendak diukur tingkat keterbacaannya dengan mengambil 100 buah perkataan. Yang dimaksud dengan kata adalah sekelompok lam-bang yang dikiri dan kanannnya ber-pembatas.

b. Hitung jumlah kalimat dari seratus buah perkataan hingga perse-puluhan terdekat. Maksudnya, jika kata yang ke 100 (wacana sampel) tidak jatuh diujung kalimat, perhitungan kalimat tidak selalu utuh, melainkan ada sisa. Sisa tersebut berupa bagian dari deretan kata-kata yang membentuk kalimat. Karena keharusan pengam-bilan sampel wacana berpatokan pada angka 100, maka sisa kata yang termasuk hitungan keseratus tersebut diper-hitungkan dalam bentuk decimal (per-sepuluhan).

c. Hitunglah jumlah suku kata dari wacana sampel hingga kata ke 100. Misalnya, sampel wacana hingga kata keseratus terdiri atas 228 suku kata.

d. Untuk wacana bahasa Indonesia, penggunaan grafik Fry masih harus ditambah satu langkah, yakni mengalikan hasil perhitungan suku kata dengan 0,6. Karena itu angka 228 x 0,6= e. Plotkan angka-angka kedalam grafik

Fry. Kolom tegak lurus menun-jukkan jumlah suku kata perseratus kata dan baris mendatar menunjuk-kan jumlah kalimat perseratus kata.

Harjasujana juga menjelaskan bahwa tingkat keterbacaan ini bersifat perkiraan. Penyimpangan mungkin ter-jadi, baik keatas maupun kebawah. Oleh karena itu, peringkat keterbacaan wa-cana hendaknya ditambah satu tingkat dan dikurangi satu tingkat. ${ }^{13}$

Selanjutnya, terkait Grafik Raygor, pertama kali diperkenalkan oleh Alton Raygor, lalu dikenal dengan formula Raygor (grafik Raygor). Grafik Raygor menilai keterbacaan berdasarkan pan-jang kalimat dan kata. Teori Raygor menyatakan bahwa semakin panjang suatu kalimat, akan lebih sulit dibaca oleh kemampuan membaca tertentu. Hal yang sama juga terjadi dengan panjang kata sebuah teks. Berikut ada-lah gambar grafik Raygor yang diper-gunakan untuk melihat keterbacaan suatu teks.

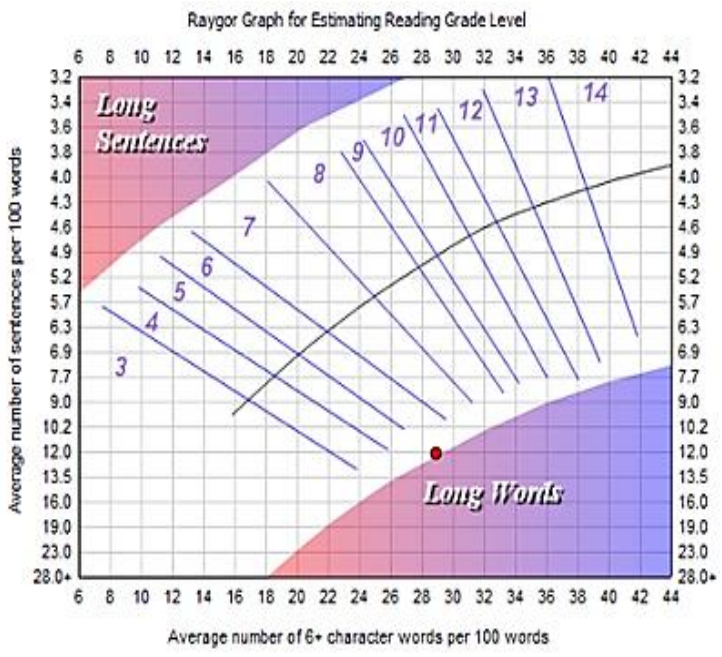

Sekolah Dasar Menggunakan Formula Grafik Fry". Jurnal Pendidikan Guru Sekolah Dasar STKIP Subang,1(2).

el Bidayah: Journal of Islamic Elementary Education Volume 1, Nomor 2, September 2020 
Petunjuk penggunaan grafik Raygor adalah sebagai berikut:

a. Langkah pertama, adalah memilih penggalan yang representative dari wacana yang hendak diukur tingkat keterbacaannya dengan mengambil 100 buah kata daripadanya. Lang-kah adalah sekelompok lambang yang kiri dan kanannya berpembatas. Penggalan wacana yang representatif artinya memilih waca-na sampel yang benarbenar men-cerminkan teks bacaan, yaitu wacana tanpa gambar, grafik, tabel, rumus, maupun kekosongan halaman.

b. Langkah kedua, menghitung rata-rata jumlah kalimat dari 100 buah perkataan tersebut hingga persepu-luhan yang terdekat.

c. Langkah Ketiga, menghitung rata-rata jumlah kata sulit perseratus buah perkataan, yaitu kata-kata yang dibentuk oleh enam huruf atau lebih. Kriteria tingkat kesulitan se-buah kata di dasari oleh panjang dan pendeknya kata. Kata yang termasuk dalam kategori sulit adalah kata yang tersusun atas enam huruf atau lebih.

d. Langkah keempat, mencari titik temu hasil yang diperoleh dari langkah kedua dan ketiga tersebut dalam grafik Raygor

\section{Pembahasan}

\section{Tingkat Keterbacaan Buku Tema-tik Kelas I}

Hasil analisis dari kedelapan buku siswa tematik terpadu kelas I ber-dasarkan grafik Fry, dan juga grafik Raygor adalah sebagai berikut.

Pada tema I menurut grafik fry buku siswa tematik terpadu kelas 1 tidak sesuai untuk siswa level kelas 1, tetapi lebih sesuai di kelas 2 karena menurut hasil perhitungan ketiga sampel yang di plotkan kedalam grafik Fry menunjuk-kan kesesuaian level tingkat keter-bacaan dikelas 2. Sementara pada grafik Raygor buku siswa tematik terpadu kelas 1 tema I terdapat kesesuaian dengan level kelas 1 dikarenakan me-nurut perhitungan ketiga sampel yang diplotkan kedalam grafik Raygor terdapat dua hasil level tingkat keterbacaan di kelas 1 , dan satu sempel menunjukkan level perkataan yang terlalu panjang.

Pada tema II menurut grafik Fry buku siswa tematik terpadu kelas 1 tidak sesuai untuk siswa level kelas 1 , tetapi lebih sesuai dikelas 2 karena menurut hasil perhitungan dua dari ketiga sampel yang di plotkan kedalam grafik Fry menunjukkan kesesuaian level tingkat keterbacaan kelas 2 , dan satu sampel yang lain menunjukkan kesesuaian pada level tingkat ke-terbacaan kelas 4. Sementara pada grafik Raygor buku siswa tematik terpadu kelas 1 tema II tidak sesuai untuk siswa level kelas 1, tetapi lebih sesuai di kelas 3 dikarenakan menurut hasil perhitungan ketiga sampel yang di plotkan kedalam grafik Raygor menunjukkan hasil level tingkat keterbacaan di kelas 3.

Pada tema III menurut grafik Fry buku siswa tematik terpadu kelas 1 tidak sesuai untuk siswa level kelas 1 , tetapi lebih sesuai di kelas 4 karena menurut hasil perhitungan dua dari ketiga sampel yang di plotkan kedalam grafik Fry menunjukkan kesesuaian level tingkat keterbacaan kelas 4, dan satu sampel yang lain menunjukkan kesesuaian level tingkat keterbacaan kelas 3. Sementara pada grafik Raygor buku siswa tematik terpadu kelas 1 tema III tidak sesuai untuk siswa level kelas 1, tetapi lebih sesuai di kelas 3 karena menurut hasil perhitungan ketiga sampel yang di plotkan kedalam grafik Raygor menunjukkan hasil level tingkat keterbacaan di kelas 3.

Pada tema IV menurut grafik Fry buku siswa tematik terpadu kelas 1 tidak sesuai untuk siswa level kelas 1, karena menurut hasil perhitungan ketiga sampel yang di plotkan kedalam grafik Fry menunjukkan kesesuaian level tingkat keterbacaan yang berbeda yaitu pada level 1,2,dan 3 . 
Oleh: Aly Mashar, Bintang Aji Permana Caromalela

Sementara pada grafik Raygor buku siswa tematik terpadu kelas 1 tema IV tidak sesuai untuk siswa level kelas 1 , tetapi lebih sesuai di kelas 3 karena menurut hasil perhitungan dua dari ketiga sampel yang di plotkan kedalam grafik Raygor menunjukkan kesesuaian level tingkat keterbacaan kelas 3 , dan satu sampel yang lain menunjukkan kesesuaian level tingkat keterbacaan di kelas 4.

Pada tema $\mathrm{V}$ menurut grafik Fry buku siswa tematik terpadu kelas 1 tidak sesuai untuk siswa level kelas 1 , tetapi lebih sesuai di kelas 2 karena menurut hasil perhitungan dua dari ketiga sampel yang di plotkan kedlam grafik Fry menunjukkan kesesuaian level tingkat keterbacaan kelas 2, dan satu sampel yang lain menunjukkan kesesuaian level tingkat keterbacaan kelas 5. Sementara pada grafik Raygor buku siswa tematik terpadu kelas 1 tema $\mathrm{V}$ tidak sesuai untuk siswa level kelas 1 , tetapi lebih sesuai di kelas 3 karena menurut hasil perhitungan dua dari ketiga sampel yang di plotkan kedalam grafik Raygor menunjukkan kesesuian level tingkat keterbacaan kelas 3, dan satu sampel yang lain menunjukkan perkataan yang terlalu panjang.

Pada tema VII menurut grafik Fry buku siswa tematik terpadu kelas 1 tidak sesuai untuk siswa level kelas 1, karena menurut hasil perhitungan ketiga sampel yang di plotkan kedalam grafik Fry menunjukkan kesesuaian level tingkat keterbacaan yang berbeda yaitu pada level 2, kata yang terlalu panjang, dan 3. Sementara pada grafik Raygor buku siswa tematik terpadu kelas 1 tema VII tidak sesuai untuk siswa level kelas1, tetapi lebih sesuai di kelas 3 karena menurut hasil perhitungan ketiga sampel yang di plotkan kedalam grafik Raygor menunjukkan kesesuaian level tingkat keterbacaan kelas 3.

Pada tema VIII menurut garfik Fry buku siswa tematik terpadu kelas 1 tidak sesuai untuk siswa level kelas 1, karena menurut hasil perhitungan ketiga sampel yang di plotkan kedalam grafik Fry menunjukkan kesesuaian level tingkat keterbacaan yang berbeda yaitu pada level 1,2,dan 3 . Sementara pada grafik Raygor buku siswa tematik terpadu kelas 1 tema VIII tidak sesuai untuk siswa level kelas 1, karena menurut hasil perhitungan ketiga sampel yang di plotkan kedalam grafik Raygor menunjukkan kesesuaian level tingkat keterbacaan yang berbeda yaitu kata yang terlalu panjang.

\section{Tingkat Keterbacaan Buku Tematik Kelas II}

Hasil analisis dari kedelapan buku siswa tematik terpadu kelas II berdasarkan grafik Fry, dan juga grafik Raygor sebagai berikut:

Pada tema I menurut grafik Fry buku siswa tematik terpadu kelas 2 tidak sesuai untuk siswa kelas 2, karena menurut hasil perhitungan ketiga sampel yang di plotkan kedalam grafik Fry menunjukkan kesesuaian level tingkat keterbacaan yang berbeda yaitu pada level 3,6,dan 2 . Sementara pada grafik Raygor buku siswa tematik terpadu kelas 2 tema I tidak sesuai untuk siswa level kelas 2, tetapi lebih sesuai di kelas 3 karena menurut hasil perhitungan dua dari ketiga sampel yang di plotkan kedlam grafik Raygor menunjukkan kesesuaian level tingkat keterbacaan kelas 3, dan satu sampel yang lain menunjukkan kesesuaian level tingkat keterbacaan kelas 5.

Pada tema II menurut grafik Fry buku siswa tematik terpadu kelas 2 tidak sesuai untuk siswa level kelas 2, karena menurut hasil perhitungan dua dari ketiga sampel yang di plotkan kedalam grafik Fry menunjukkan kesesuaian level tingkat keterbacaan kelas 3, dan satu sampel yang lain menunjukkan kesesuaian level tingkat keterbacaan kelas 4. Sementara pada grafik Raygor buku siswa tematik terpadu kelas 2 
tema II tidak sesuai untuk siswa level kelas 2 , tetapi lebih sesuai di kelas 3 karena menurut hasil perhitungan dua dari ketiga sampel yang di plotkan kedalam grafik Raygor menunjukkan kesesuaian level tingkat keterbacaan kelas 3, dan satu sampel yang lain menunjukkan kesesuaian level tingkat keterbacaan kelas 4 .

Pada tema III menurut grafik Fry buku siswa tematik terpadu kelas 2 tidak sesuai untuk siswa level kelas 2, karena menurut hasil perhitungan dua dari ketiga sampel yang diplotkan kedalam grafik Fry menunjukkan kesesuaian level tingkat keterbacaan kelas 1, dan satu sampel lain menunjukkan kata yang terlalu panjang, Sementara pada grafik Raygor buku siswa tematik terpadu kelas 2 tema III tidak sesuai untuk siswa level kelas 2, tetapi lebih sesuai di kelas 3 karena menurut hasil perhitungan dua dari ketiga sampel yang diplotkan kedalam grafik Raygor menunjukkan kesesuaian level tingkat keterbacaan kelas 3, dan satu sampel lain menunjukkan kata yang terlalu panjang.

Pada tema IV menurut grafik Fry buku siswa tematik terpadu kelas 2 sesuai untuk siswa level kelas 2, karena menurut hasil perhitungan dua dari ketiga sampel yang di plotkan kedalam grafik Fry menunjukan kesesuaian level tingkat keterbacaan kelas 2, dan satu sampel lain menunjujjan kesesuaian level tingkat keterbacaan kelas 4. Sementara pada grafik Raygor buku siswa tematik terpadu kelas 2 tema IV tidak sesuai untuk siswa level kelas 2, tetapi lebih sesuai di kelas 3 karena menurut hasil perhitungan ketiga sampel yang di plotkan kedalam grafik Raygor menunjukkan kesesuaian level tingkat keterbacaan kelas 3.

Pada tema $\mathrm{V}$ menurut grafik Fry buku siswa tematik terpadu kelas 2 tidak sesuai untuk siswa level kelas 2, karema menurut hasil perhitungan dua dari ketiga sampel yang di plotkan kedalam grafik Fry menunjukkan kesesuaian level tingkat keterbacaan kelas 1, dan satu sampel lain menunjukkan level tingkat keterbacaan kelas 2. Sementara pada grafik Raygor buku siswa tematik terpadu kelas 2 tema $V$ tidak sesuai untuk siswa level kelas 2 karena menurut hasil perhitungan ketiga sampel yang di plotkan kedalam grafik Raygor menunjukkan kesesuaian level tingkat keterbacaan yang berbeda yaitu pada level kata yang terlalu panjang,2, dan 1 .

Pada tema VI menurut grafik Fry buku siswa tematik terpadu kelas 2 sesuai untuk siswa level kelas 2, karena menurut hasil perhitungan ketiga sampel yang di plotkan kedalam grafik Fry menunjukkan kesesuaian level tingkat keterbacaan kelas 2. Sementara pada grafik Raygor buku siswa tematik terpadu kelas 2 tema VI sesuai untuk siswa kelas 2, karena menurut hasil perhitungan dua dari ketiga sampel yang di plotkan kedalam grafik Raygor menunjukkan kesesuaian level tingkat keterbacaan kelas 2, dan satu sampel yang lain menunjukkan level tingkat keterbacaan kelas 3.

Pada tema VII menurut grafik Fry buku siswa tematik terpadu kelas 2 tidak sesuai untuk siswa level kelas 2, karena menurut hasil perhitungan ketiga sampel yang di plotkan kedalam grafik Fry menunjukkan kesesuaian level tingkat keterbacaan yang berbeda yaitu pada level 3,1 dan 4 . Sementara pada grafik Raygor buku siswa tematik terpadu kelas 2 tema VI tidak sesuai untuk siswa level kelas 2, karena menurut hasil perhitungan dua dari ketiga sampel yang di plotkan kedalam grafik Raygor menunjukkan kesesuaian level tingkat keterbacaan kelas 3,dan sampel yang lain menunjukkan kesesuaian level tingkat keterbacaan kelas 1 .

Pada tema VII menurut grafik Fry buku siswa tematik terpadu kelas 2 tidak sesuai untuk siswa level kelas 2, karena menurut hasil perhitungan ketiga sampel yang di plotkan kedalam grafik Fry menunjukkan 
Oleh: Aly Mashar, Bintang Aji Permana Caromalela

kesesuaian level tingkat keterbacaan yang berbeda yaitu kelas 4,3,dan 2. Sementara pada grafik Raygor buku siswa tematik terpadu kelas 2 tema VIII tidak sesuai untuk siswa level kelas 2, karena menurut hasil perhitungan dua dari ketiga sampel yang di plotkan kedalam grafik Raygor menunjukkan kesesuaian level tingkat keterbacaan kelas 3,dan sampel yang lain menunjukkan kesesuaian level tingkat keterbacaan kelas 4 .

\section{Tingkat Keterbacaan Buku Tema-tik Kelas 3}

Hasil analisis dari kedelapan buku siswa tematik terpadu kelas berdasarkan grafik Fry dan juga grafik Raygor sebagai berikut:

Pada tema I menurut grafik Fry buku siswa tematik terpadu kelas 3 tidak sesuai untuk siswa level kelas 3, karena menurut hasil perhitungan ketiga sampel yang diplotkan kedalam grafik Fry menunjukkan kesesuaian level tingkat keterbacaan kelas 3, dan sampel yang lain menunjukkan kesesuaian level tingkat keterbacaan kelas 6. Sementara pada grafik Raygor buku siswa tematik terpadu kelas 3 tema II tidak sesuai untuk siswa level kelas 3, karena menurut hasil perhitungan ketiga sampel yang di plotkan kedalam grafik Raygor menunjukkan kesesuaian level tingkat keterbacaan yang berbeda yaitu kelas 4,5,dan 4 .

Pada tema III menurut grafik Fry buku siswa tematik terpadu kelas 3 tidak sesuai untuk siswa level kelas 3, karena menurut hasil perhitungan ketiga sampel yang di plotkan kedalam grafik Fry menunjukkan kesesuaian level tingkat keterbacaan yang berbeda yaitu kelas 2,6,dan 3. Sementara pada grafik Raygor buku siswa tematik terpadu kelas 3 tema III tidak sesuai untuk siswa level kelas 3, karena menurut hasil perhitungan ketiga sampel yang di plotkan kedalam grafik Raygor menunjukkan ke- sesuaian level tingkat keterbacaan yang berbeda yaitu kelas 1,5,dan 3 .

Pada tema IV menurut grafik Fry buku siswa tematik terpadu kelas 3 tidak sesuai untuk siswa level kelas 3, karena menurut hasil perhitungan dua dari ketiga sampel yang diplotkan kedalam grafik Fry menunjukkan level tingkat keterbacaan kelas 4,dan sampel yang lain menunjukkan kesesuaian level tingkat keterbacaan kelas 6. Sementara pada grafik Raygor buku siswa tematik terpadu kelas 3 tema IV sesuai untuk siswa level kelas 3, karena menurut hasil perhitungan dua dari ketiga sampel yang di plotkan kedalam grafik Raygor menunjukkan level tingkat keterbacaan kelas 3,dan sampel yang lain menunjukkan kesesuaian level tingat keterbacaan kelas 5.

Pada tema $\mathrm{V}$ menurut grafik Fry buku siswa tematik terpadu kelas 3 tidak sesuai untuk siswa level kelas 3, karena menurut hasil perhitungan dua dari ketiga sampel yang di plotkan kedalam grafik Fry menunjukkan level tingkat keterbacaan kelas 5, dan sampel yang lain menunjukkan kesesuaian level tingkat keterbacaan kelas 6. Sementara pada grafik Raygor buku siswa tematik terpadu kelas 3 tema $V$ sesuai untuk siswa level kelas 3, karena menurut hasil perhitugan dua dari ketiga sampel yang di plotkan kedalam grafik Raygor menunjukkan level tingkat keterbacaan kelas 3,dan sampel yang lain menunjukkan kesesuaian level tingkat keterbacaan kelas 4.

Pada tema VI menurut grafik Fry buku siswa tematik terpadu kelas 3 tidak sesuai untuk siswa level kelas 3, karena menurut hasil perhitungan dua dari ketiga sampel yang di plotkan kedalam grafik Fry menunjukkan kesesuaian level tingkat keterbacaan kelas 1, dan sampel yang lain menunjukkan kesesuaian level tingkat keterbacaan kelas 3. Sementara pada grafik Raygor buku siswa tematik terpadu kelas 3 
tema VI sesuai untuk siswa level kelas 3, karena menurut hasil perhitungan dua dari ketiga sampel yang di plotkan kedalam grafik Raygor menunjukkan level tingkat keterbacaan kelas 3,dan sampel yang lain menunjukkan kata yang terlalu panjang.

Pada tema VII menurut grafik Fry buku siswa tematik terpadu kelas 3 tidak sesuai untuk siswa level kelas 3, karena menurut hasil perhitungan ketiga sampel yang di plotkan kedalam grafik Fry menunjukkan level tingkat keterbacaan yang berbeda yaitu kelas 3,2,dan 5. Sementara pada grafik Raygor buku siswa tematik terpadu kelas 3 tema VII sesuai untuk siswa level kelas 3, karena menurut hasil perhitungan ketiga sampel yang di plotkan kedalam grafik Raygor menunjukkan kesesuaian level tingkat keterbacaan kelas 3 .

Pada tema VIII menurut grafik Fry buku siswa tematik terpadu kelas 3 tidak sesuai untuk siswa kelas 3, karena menurut hasil perhitungan dua dari ketiga sampel menunjukkan kesesuaian level tingkat keterbacaan kelas 6, dan sampel yang lain menunjukkan kesesuaian level tingkat keterbacaan kelas 5. Sementara pada grafik Raygor buku siswa tematik terpadu kelas 3 tema VIII sesuai untuk siswa level kelas 3, karena menurut hasil perhitungan dua dari ketiga sampel menunjukkan kesesuaian level tingkat keterbacaan kelas 3, dan sampel yang lain menunjukkan kesesuaian level tingkat keterbacaan kelas 5 .

Dengan demikian dapat di simpulkan bahwa buku siswa tematik terpadu kelas 1 tema I sampai dengan tema VIII lebih cocok digunakan pada level tingkat keterbacaan kelas 2,3,dan 4, sementara buku siswa tematik terpadu kelas 2 tema I sampai dengan tema VIII lebih cocok digunakan pada level tingkat keterbacaan kelas 3,dan 2, dan buku siswa tematik terpadu kelas 3 tema I sampai dengan tema VIII lebih cocok digunakan pada level tingkat keterbacaan kelas 3,5, dan 6 .

\section{Kesimpulan}

Berdasarkan hasil penelitian untuk melihat tingkat keterbacaan buku siswa tematik terpadu kurikulum 2013 pada kelas rendah terbitan Kementerian Pen-didikan dan Kebudayaan tahun 2017, dan tahun 2015 menggunakan alat ukur keterbacaan grafik Fry, dan grafik Raygor dapat ditarik kesimpulan sebagai berikut. Tingkat keterbacaan buku siswa tematik terpadu kurikulum 2013 pada kelas 1 tema I sampai dengan tema VIII tidak sesuai tingkat keterbacaannya. Sementara tingkat keterbacaan buku siswa tematik terpadu kurikulum 2013 pada kelas 1 tema I sampai dengan tema VIII kurang sesuai tingkat keterbacaannya menurut grafik Raygor, karena terdapat 1 tema buku siswa tematik terpadu yang sesuai dengan level kelas 1 , sedangkan 7 tema yang lain lebih sesuai untuk level kelas 3. Tingkat keterbacaan buku siswa tematik terpadu kurikulum 2013 pada kelas 2 tema I sampai dengan tema VIII kurang sesuai tingkat keterbacaannya. Tingkat keterbacaan buku siswa tematik terpadu kurikulum 2013 pada kelas 3 tema I sampai dengan tema VIII kurang sesuai tingkat keterbacaannya menurut grafik Fry, karena hanya terdapat 1 tema buku siswa tematik terpadu yang level tingkat keterbacaannya sesuai untuk level kelas 3, sedangkan 7 tema yang lain lebih sesuai untuk level kelas 5,6, dan 1.

\section{Daftar Pustaka}

Arif, Syamsul dkk. 2016. "Keterbacaan Buku Teks Bahasa Indonesia Kurikulum 2013 Kelas VII dengan Grafik Raygor". Jurnal Fakultas Bahasa dan Seni,3 (2).

Didin Budiman. 201. Karakteristik Siswa Sekolah Dasar.Bahan Ajar Mata Kuliah Penjas Universitas Muhammadiyah Sidoarjo.

Direktorat Jenderal Pendidikan Dasar. 2013. Panduan Teknis Memahami Buku Siswa dan Buku Guru dalam 
Oleh: Aly Mashar, Bintang Aji Permana Caromalela

Pembelajaran di Sekolah Dasar. Jakarta: Kementerian Pendidikan dan Kebudayaan.

Direktorat Jenderal Pendidikan Dasar. 2013. Panduan Teknis Pembelajaran Tematik Terpadu dengan Pendekatan Saintifik di Sekolah Dasar. Jakarta: Kementerian Pendidikan dan Kebudayaan.

Euis Ananih, Nesa Nuthasanah. 2016." Tingkat Keterbacaan Wacana Pada Buku Paket Kurikulum 2013 Kelas 4 Sekolah Dasar Menggunakan Formula Grafik Fry". Jurnal Pendidikan Guru Sekolah Dasar STKIP Subang, 1(2).

Faisal. 2017. Buku tematik kurikulum 2013 Kelas II tema Hidup Bersih dan Sehat. Jakarta: Kementerian Pendi-dikan dan Kebudayaan..

Holofatuz,N. 2015." Analisis Tingkat Keterbacaan dalam Buku Teks Pembelajaran Tematik Terpadu Kurikulum 2013 Tingkat SD/MI Kelas 2". NOSI, 3(2).

Iba Muhibba, dkk.Buku tematik kurikulum 2013 Kelas III tema Peduli Lingkungan Sosial. Jakarta: Kementerian Pendidikan dan Kebudayaan.

Irene Maria Juli Astuti, dkk. 2017. Buku tematik kurikulum 2013 Kelas II tema Merawat Hewan dan Tumbuhan.Jakarta: Kementerian Pendidikan dan Kebudayaan.

Ketut Ngurah Yasa. 2013. "Kecermatan Formula Keterbacaan Sebagai Penentu Kefefktifan Teks ".Jurnal Pendidikan dan Pengajaran, 46 (2): 238-245.

Moeleong, J Lexy. 2016. Metodologi Penelitian Kualitatif Edisi Revisi. Bandung:PT Remaja Rosdakarya.

Nurhasanah,dkk. 2015. Buku tematik kurikulum 2013 Kelas III tema Bersahabat dengan Semua Ciptaan Tuhan. Jakarta: Kementerian Pendidikan dan Kebudayaan. Pengembangan Bahan Ajar Modul Ilmu Pengetahuan Alam Bagi Siswa Kelas VI SD PGMI FAI Universitas Muhammadiyah Sidoarjo.

Nurhasanah dan Lubna Asegaf.2017.Buku tematik kurikulum 2013 Kelas I tema Kegiatanku. Jakarta: Kemen-terian Pendidikan dan Kebu-dayaan.

Novilana Adelina,dkk. 2017. Buku Tematik Terpadu Kurikulum 2013 Kelas I Tema Kegemaranku. Jakarta: Kementerian Pendidikan dan Kebudayaan.

Sari Kusuma Dewi, dkk. 2015. Buku tematik kurikulum 2013 Kelas III tema Perubahan di Alam. Jakarta: Kementerian Pendidikan dan Kebudayaan.

Purnomosidi. 2017. Buku tematik kurikulum 2013 Kelas II tema Kebersamaan. Jakarta: Kementerian Pendidikan dan Kebudayaan.

Sari Kusuma Dewi.2015.Buku tematik kurikulum 2013 Kelas III tema Permainan Tradisional.Jakarta:Kementerian Pendidikan dan Kebudayaan.

Setio Isnoyo, dkk. 2017. Buku tematik kurikulum 2013 Kelas I tema Keluargaku. Jakarta: Kementerian Pendidikan dan Kebudayaan.

Sunanih. 2017. "Kemampuan Membaca Anak Sekolah Dasar Kelas Rendah Bagian dari Pengembangan Bahasa". Jurnal Kajian Penelitian Pendidikan dan Pembelajaran. 2 (1).

Sonya Sinyanyuri,dkk.2015.Buku tematik kurikulum 2013 Kelas III tema Bersahabat dengan Ciptaan Tuhan .Jakarta:Kementerian Pendidikan dan Kebudayaan.

Sonya Sinyanyuri. 2015. Buku tematik kurikulum 2013 Kelas III tema Bumi dan Alam Semesta. Jakarta: Kementerian Pendidikan dan Kebudayaan. Volume 1, Nomor 2, September 2020 
Taufina. 2017. Buku tematik kurikulum 2013 Kelas II tema Pengalamanku. Jakarta: Kementerian Pendidikan dan Kebudayaan.

Yuli Kusumawati,dkk. 2017. Buku Tematik Terpadu Kurikulum 2013 Kelas I Tema Peristiwa Alam. Jakarta: Kementerian Pendidikan dan Kebudayaan.

Yusfana Hendrafriana ,dkk.2017.Buku tematik kurikulum 2013 Kelas I tema Diriku. Jakarta: Kementerian Pendidikan dan Kebudayaan. 